\title{
ترجيحات الإمام أبي عبيد القاسم بن سلاّم بن عبد الله الهروي في الزكاة من كتاب الأموال
}

\author{
Muthoifin, Sudarno Humaidi \\ Magister Hukum Islam Universitas Muhammadiyah Surakarta \\ E-Mail: mut122@ums.ac.id
}

\begin{abstract}
The needs of low income families hasn't been fulfilled as it should be. Even poverty issues hasn't been solved yet. Therefore, the writer willing to involve in solving the issue by presenting the results of Tarjih from Ulama who's mastered in so many religious disciplines. He lives in Imam Syafi'ie and imam Ahmad's era. He is famous with his ability in Arabic language. He is Qasim bin Salaam, which commonly known as Abu Ubaid. He states on his book (Kitabul Amwal) Varieties of sources of public wealth managed by the government. Some of them are taxes, Ghanimah, Fa'i, Zakat and so many more. Meanwhile the writer only picks Zakat as his research object. This is because all Muslims have the ability and freewill to manage it at the maximum level. The writer limits his research into two points: first: what is the results of Abu Ubaid's Tarjih. Second: what is the method of Abu Ubaid in his Tarjih. The main purpose of this research is to know his tarjeh and the basis of it. While providing benefits to Amil zakat, fatwa institutions, and alike. So that the result of this research serve as a reference in regulating the wealth allocation on Zakat and in issuing fatwa. The conclusions of the research is: That in general Abu ubaid uses the method (manhaj) of the majority of ulama in interact with Dalils that looks contradictive. First, he tried to colaborate (jam'u) two Dalils that contradictive. Then if it can't be collaborated, he chooses (tarjih) one of the two Dalils without using the others. He wasn't do Naskh because he was able to Tarjih the whole problem of zakat in his book. If there is two Dalils that contradictive, he'll choose the Shohih one. He put Dalil first rather than Atsar and Qiyas. However if the Dalil is Dhoif he will choose Atsar and Qiyas. He put Atsar of the shohabat first rather than the words of ulama after them. If there is two Qiyas that contradictive, he'll choose Qiyas that supported with Dalils or in accordance with the general rules of the religions.
\end{abstract}

Keywords: Tarjih, Abu Ubaid, zakat, and Kitabul Amwal.

Abstrak: Kebutuhan orang-orang yang berkekurangan belum terpenuhi sebagaimana
mestinya. Bahkan kefakiran dan kemiskinan juga belum teratasi. penelitian ini sebagai wujud
dari andil kami dalam menuntaskan masalah tersebut dengan cara mempersembahkan hasil
Tarjih seorang ulama yang menguasai banyak disiplin ilmu Agama, hidup di masa imam
Syafi'i dan imam Ahmad dan terkenal sebagai ahli bahasa Arab. Dia adalah Qosim bin
Sallam yang biasa disebut Abu Ubaid. Dalam bukunya (Kitabul Amwal) ia menulis
bermacam-macam sumber kekayaan umum yang dikelola olah Negara. Seperti pajak,
Ghonimah, Fa'i', Zakat dan lain sebagainya. Permasalahan Zakatlah yang kami pilih
sebagai obyek penelitian karena umat Islam memiliki kemampuan dan kebebasan untuk
mengelolanya secara maksimal. Penelitihan ini kami batasi pada dua point saja: Pertama:
Apa saja hasil Tarjeh Abu Ubaid. Kedua : Sebab atau landasan beliau dalam mentarjih.
Tujuan utama dari penelitihan ini adalah mengetahui hasil Tarjeh Abu Ubaid serta
landasannya dan memberikannya kepada lembaga-lembaga amil Zakat, lembaga-lembaga 
fatwa, dan yang serupa dengan itu. Agar hasil penelitihan ini dijadikan sebagai bahan rujukan dan pertimbangan dalam mengatur harta Zakat dan mengeluarkan fatwa. Kesimpulan dari penelitihan ini bahwa secara umum Abu Ubaid menggunakan methode (Manhaj) mayoritas Ulama dalam berinteraksi dengan dalil-dalil yang kelihatannya bertentangan. Yaitu pertama-tama ia berusaha mengkolaborasi (Jam'u) dalil-dalil yang bertentangan. Jika tidak dapat dikolaborasikan, maka ia memilih (mentarjih) salah satu dari dalil-dalil tersebut. Ia tidak melakukan Naskh karena sanggup mentarjih seluruh permasalahan Zakat dalam bukunya. Jika ada dalil-dalil yang bertentangan, maka ia memilih (mentarjih) salah satu yang ia anggap Shohih. Jika ada Hadits, Atsar dan Qiyas saling bertentangan, maka ia mendahulukan Hadits dari pada Atsar dan Qiyas, jika Hadits tersebut Shohih. Jika Haditsnya Dhoif, ia lebih memilih Atsar dan Qiyas. Jika hanya terdapat satu Hadits dalam suatu masalah, jika Hadits tersebut dikuatkan oleh Atsar atau Qiyas, maka ia tetap mengambilnya meskipun Dhoif. Ia mengutamakan Atsar Sabahat dari pada perkataan ulama setelah mereka. Jika ada dua Qiyas yang bertentangan beliau memilih Qiyas yang didukung oleh dalil atau sesuai dengan kaidah-kaidah umum Agama.

Kata kunci: Tarjih, Abu Ubaid, Zakat dan Kitabul Amwal.

الملخص: إن محا يدفع الباحث إلى اختيار هذا الموضوع ما يجري في واقع الحياة بمحتمعنا أن حوائج المحتاجين لم تسد على الوجه المطلوب والفقر والحرمان لم يمحا من الوجود ـ فأراد الباحث إسهام ما استطاع لأجل المشاركة في حل هذه القضية بتقلديم ترجيحات أبي عبيد القاسم بن سالاّم الهروي في مسائل الزكاة ـ لأنه عالم متقن في كثير من الفنون الإسلامية ومن معاصري الإمامين الشافعي وأحمد وممن يقبله الناس. اختار الباحث مسائل الزكاة من كتابه لتكون موضوعا لبحثه لأن المسلمين لايزالون في سعة وقدرة في تنفيذها بخلاف المسائل الأخرى ـ وحدد الباحث نقطتين لبحثه ـ الأولى ترجيحاته والثانية أسباب ترجيحاته وتعليلاتَا ـ مستهدفا معرفة ترجيحات أبي عبيد وأسبابها ، لتكون مرجعا للقائمين بجمع الزكاة وصرفها في مواضعها ، وليسترشدوا بها في تطبيقاتم لأحكام الزكاة . كما استهدف إبراز جانب الفقه في شخصية أبي عبيد . والمنهج الذي أسير عليه في كتابة هذا البحث هو ذكر أقوال الفقهاء التي ذكرها أبو عبيد وأدلة كل قول بائجاز ، ثم أذكر ترجيحاته مع بيان أسباهما وتعليالاكما ـ ثم أذكر موقفي من ترجيحاته موافقة أو مخالفة مع بيان أسباب ذلك. وقد توصل الباحث إلى التنيجة التي تتلخص فيما يلي : إن أبا عبيد قد هج منهج الجمهور في التعامل بين النصوص الشرعية التي ظاهرها التعارض • حيث إنه حاول الجمع بينها أولا ، وإذا لم يمكنه ذلك قام بترجيحها ـ ولم يدخل أبو عبيد في النسخ لأنه استطاع ترجيح جميع مسائل الزكاة في كتابه . وعند التعارض بين النصوص قام بترجيح النص الصحيح • وعند التعارض بين النص والآثار والقياس فإنه رجح النص عليها إن كان صحيحا ، وإذا كان ضعيفا فإنه رجح الآثار والقياس عليه . وإذا لم يوجد 
في المسألة إلا حديث واحد فإنه أخذه بشرط أن تكون هناك آثار وقياس تشهد له وتؤيده ، وإن لم تكن هناك آثار وقياس تشهد له وتؤيده فإنه لا يأخذه ـ قدم أبو عبيد آثار الصحابة على أقوال من

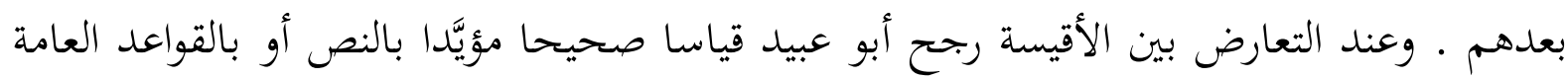
في الدين على قياس فاسد عير معتبر ـ وقد يرجح بين أقوال الفقهاء بناء على مهارته في تفسير ألفاظ النصوص الشرعية. الكلمات الرئيسة: ترجيح، أبو عبيد، الزكاة، كتاب الأموال.

\section{المقدمة}

إن من تمام نعم الله على هذه الأمة أن أرسل إليهم سيد الأولين والآخرين خحاتم الأنبياء والمرسلين رسول الله محمد ، وأنزل عليه الكتاب مهيمنا على الكتب السابقة ـ وألزم على هذه الأمة

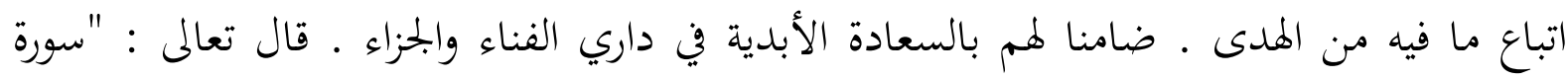

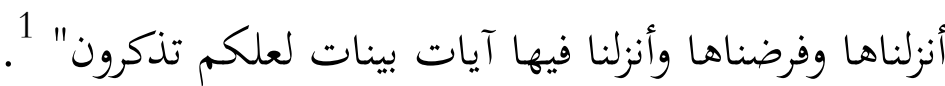
وأوحى الله تعالى إلى رسوله ما يفسر الكتاب ويبيّن مراده ـ وهو السنة المطهرة التي حاجة الكتاب إليه أشد من حاجته إلى الكتاب ـ وتضمّن تعالى لمن تمسّك بهما أن لن يضلّ في الدنيا ولا مالِ يشقى في الآخرة ـ وجعل اتباع السنة برهانا على محبته تعالى ـ قال تعالى " قل إن كنتم تحبون الله فاتبعولي يحببكم الله ويغفر لكم ذنوبكم والله غفور رحيم" . 2.

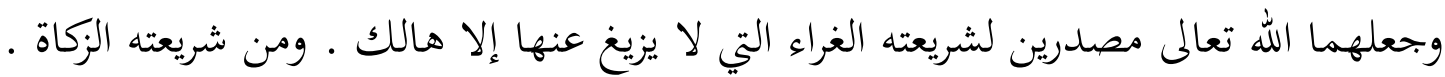
وهي ثالث دعائم الإسلام بعد الشهادتين والصلاة ـ وهي جسر متدّّ بين الطبقات الغنية والطبقات الفقيرة في المجتمع المسلم ليتم التضامن الاجتماعي بين أفرادهم ـ وهي علاج رباتي لحل مشكلة الفقر والحرمان ليصير بها المال متداولا في جميع الطبقات ، فسدّت حوائج المحتاجين وعمّت الرفاهية

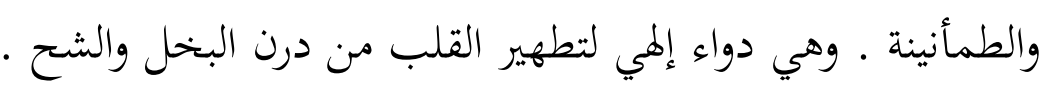

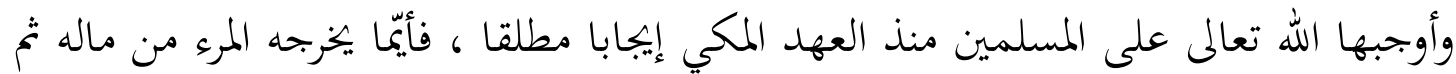

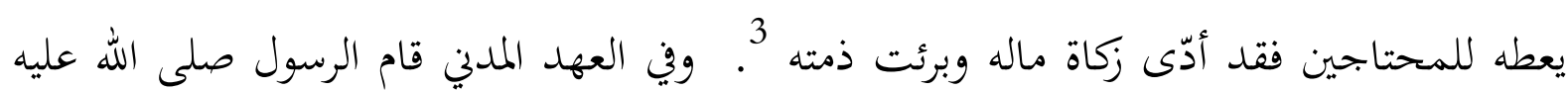

$$
\begin{aligned}
& 1
\end{aligned}
$$

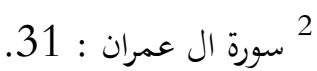

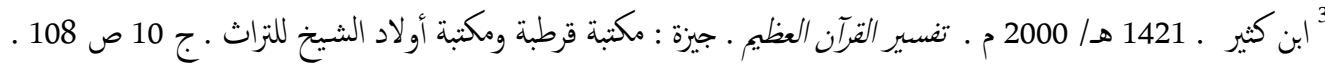


وسلم ببيان الزكاة خير قيام ، بيّن الأموال التي بتب فيها الزكاة وأنصباءها والمقادير التي يجب أن تخرج منها ومستحقيها. والصحابة في عصرهم طبّقوا أحكام الزكاة في واقع الحياة اهتداء بسنة النبي صلى الله عليه

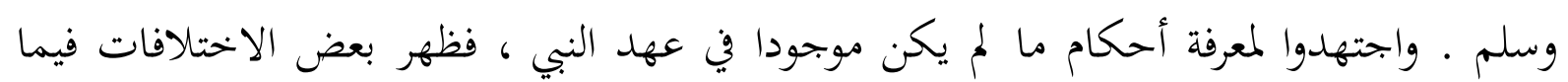

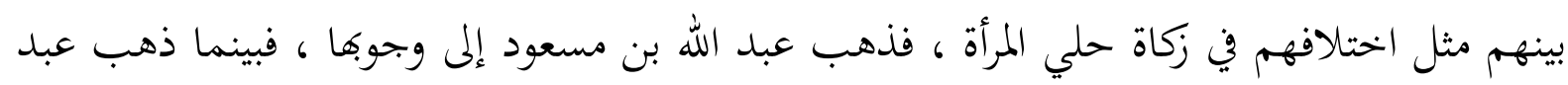

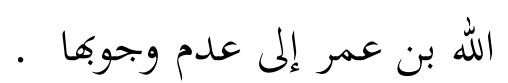

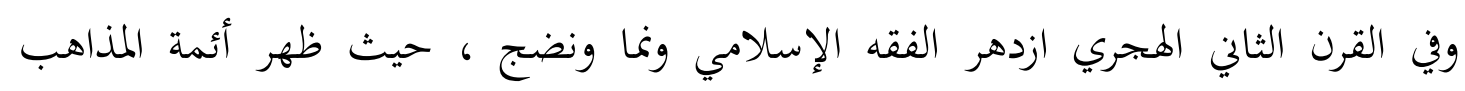

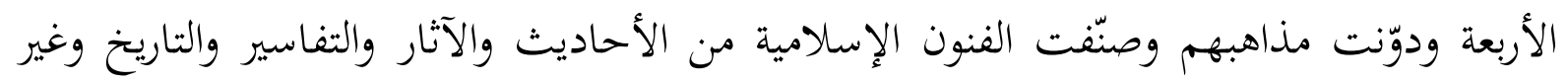
ذلك في هذا العصر ـ فمما ترتب على ذلك كله وقوع الاختلافات في المسائل الفقهية بين الفقهاء

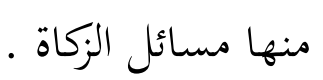

فأمام هذه الاختلافات ظهرت بحموعة من العلماء الذين يعتنون بالترجيح بين أقوال الفقهاء

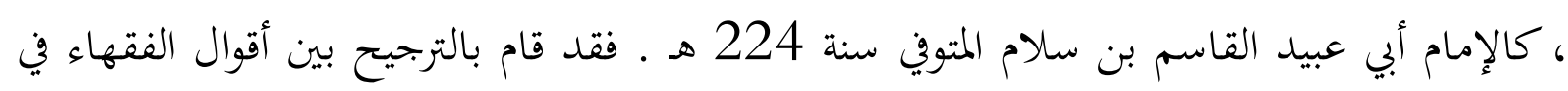

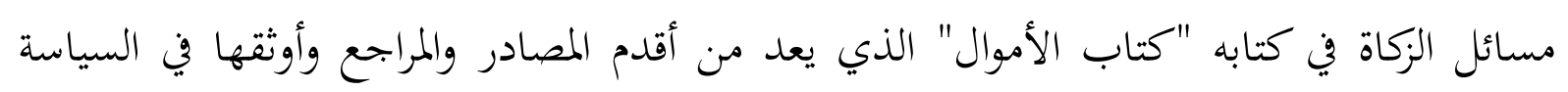

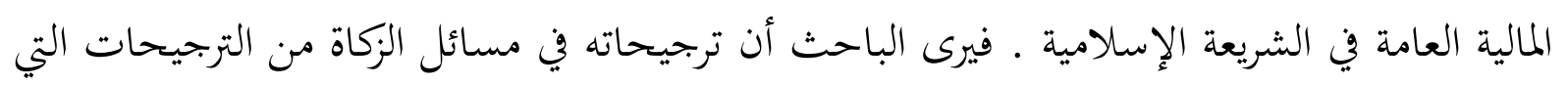

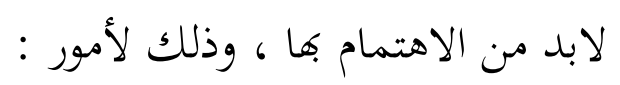
الأول : إن الإمام أتقن في أصناف الفنون الإسلامية من القراءات والتفسير واللغة والتاريخ

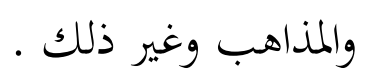
الثاني : وإنه أكثر إدراكا لأقوال المذاهب ، حيث عاش في عصر الذهبي لتطور الفقه الإسلامي ونمائه ونضجه ، وهو من معاصري الإمام أحمد بن حنبل رحمه الله تعالى المتوفي سنة 241 إنه

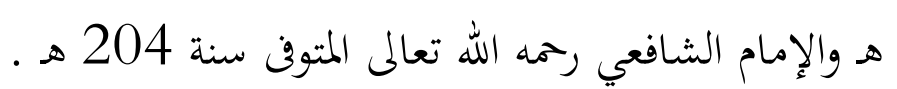

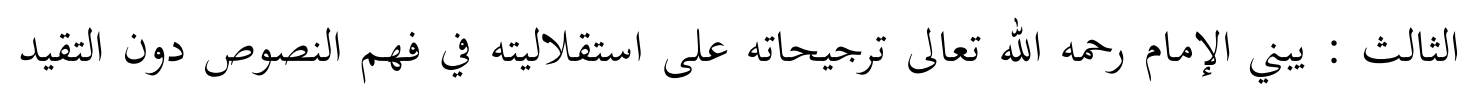

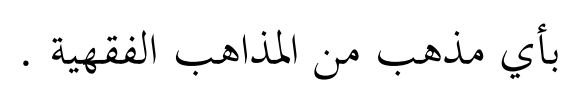
الرابع : هذا الكتاب يعد من أقدم المصادر والمراجع وأوثقها في السياسة المالية العامة في الشريعة الإسلامية ـ وترجيحاته تعتبر من أقدم الترجيحات في هذا الأمر. 
إن مما يجري في واقع الحياة بمحتمعنا أن حوائج المحتاجين لم تسد على الوجه المطلوب وأن الفقر والحرمان لم تمح من الوجود ـ فأدرك الباحث أن من أسباب هذه القضية عدم تفعيل الأموال

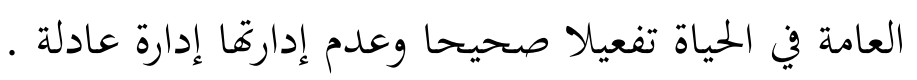

فأراد الباحث إسهام ما استطاع لأجل المشاركة في حل هذه القضية بتقديم ترجيحات أبي

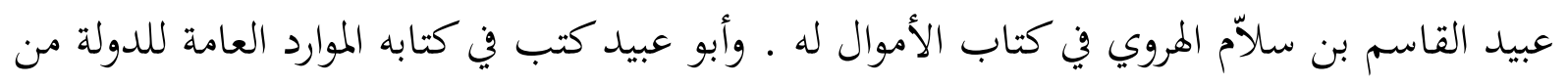
غنيمة وفيء وخراج وعشر وجرية وزكاة ـ إلا أن الباحث الختار مسائل الزكاة من كتابه لتهابل لتكون

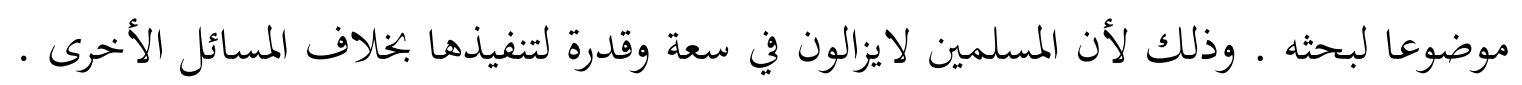
وحدد الباحث نقطتين لبحثه : الأولى : ترجيحاته ـ والثانية : أسباب ترجيحاته وتعليلاتما . ويهدف الباحث إلى معرفة ترجيحات أبي عبيد وأسباهما ، لتكون مرجعا للقائمين بجمع الزكاة

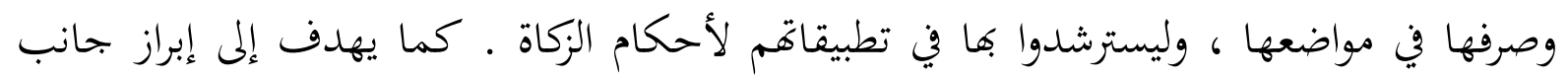

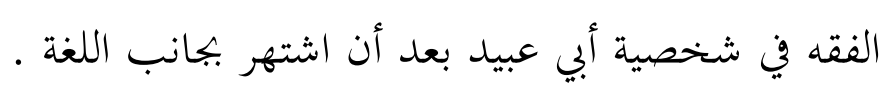

\section{1}

إن كتاب الأموال يعد من أحسن الكتب في الفقه وأجودها ـ ـ قال الخظيب البغدادي

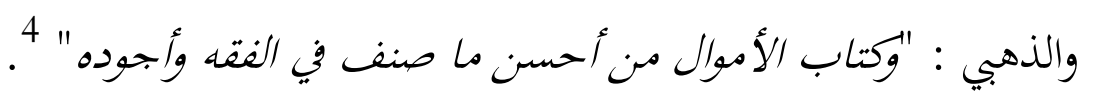
أذكر هنا ميزاته على الكتب الأخرى التي وصلت إلي وأقتنيها .

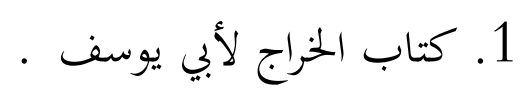

امتاز كتاب الأموال لأبي عبيد عليه باستيعابه للقضايا المالية وأيراده النصوص الكثيرة من

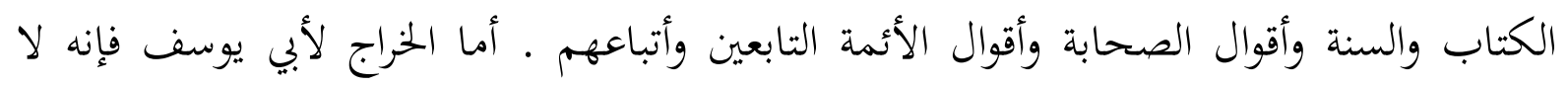

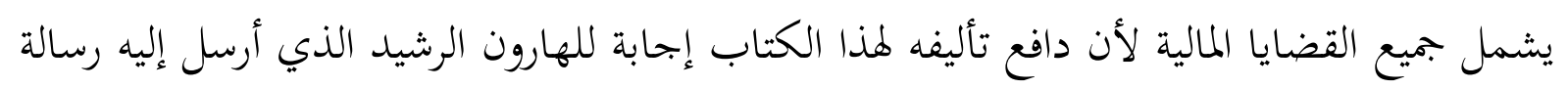

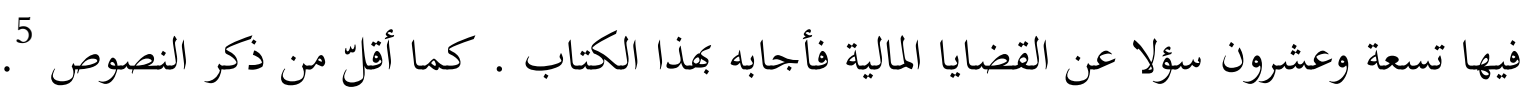
2. كتاب الخراج ليحيى بن آدم .

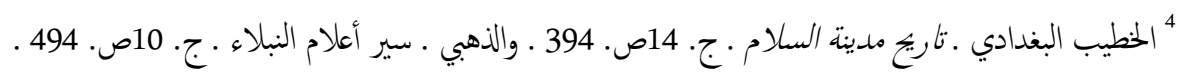

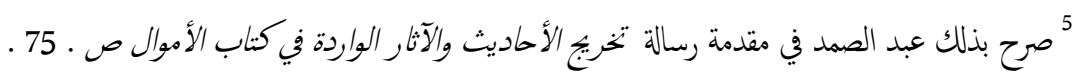


امتاز كتاب الأموال لأبي عبيد عليه بذكر أقوال الصحابة والتبعين وأتباعهم والأئمة واختلافهم ومناقشة كل قول ثم اختيار الراجح عنده ، أما الخراج ليحيى بن آدم فإنه لا يذكر الآراء

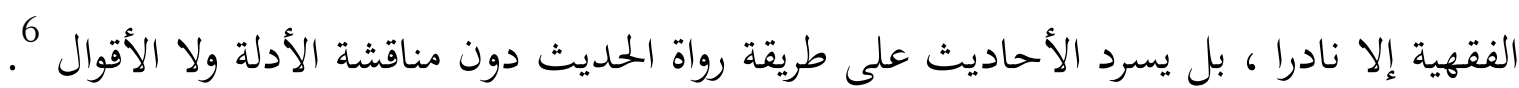
3. كتاب الأموال لحميد بن زبنويه .

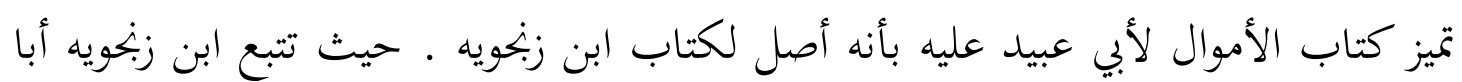

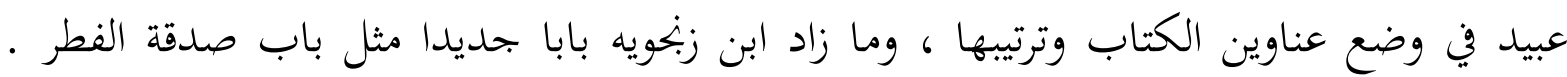

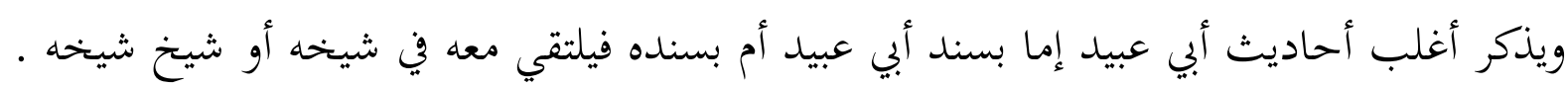

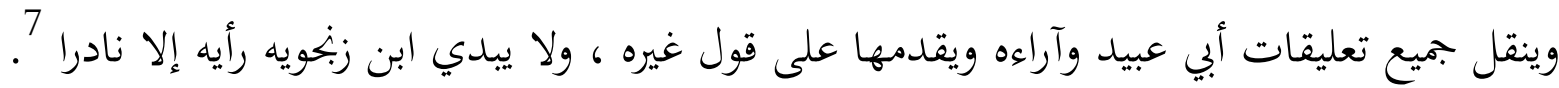

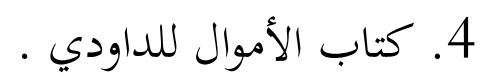

تميز كتاب الأموال لأبي عبيد عليه باعتماد الداودي في تصنيف كتابه على كتابه ، وبشمول كتاب أبي عبيد لموضوعات القضايا المالية واحتوائه على الآراء ، بخلاف الأموال للداودي فئل فإنه اقتصر

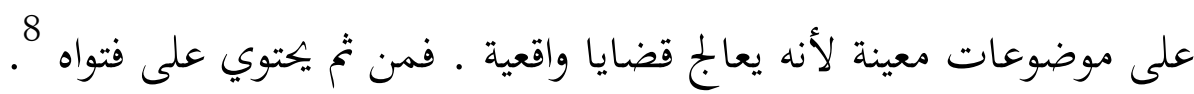

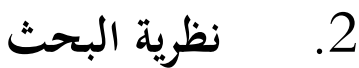

إن النظرية التي سار عليها الباحث هي نظرية الترجيح لدى جمهور الفقهاء في التعامل بين النصوص التي ظاهرها التعارض . إن الترجيح عندهم مرحلة ثانية من مراحل ثلاث في التعامل مع المتعارضين ـ وذلك لأفم إذا وجدوا المتعارضين ذهبوا إلى الجمع لأنه أولى من الترجيح ، فني الجمع إعمال الدليلين وفي الترجيح

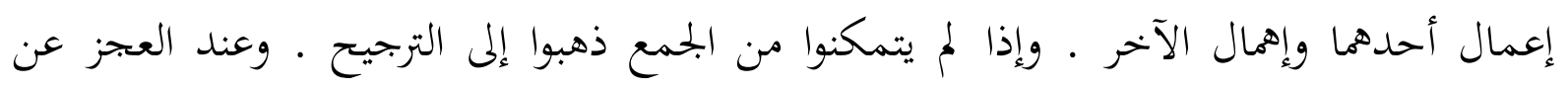

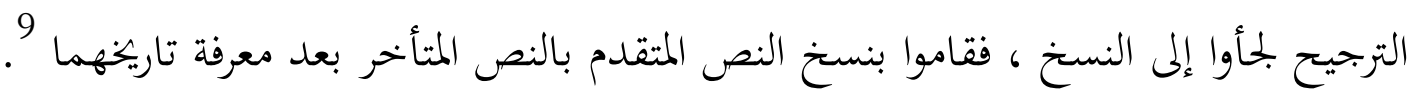
والتعارض عندهم لا يخلو من ثلاث أحوال 10 : الأولى : التعارض بين المنقولين .

$$
\text { 6 صرح بذلك عبد الصمد في مقدمة رسالة تخريج الأحاديث والآثار الواردة في كتاب الأموال .ص. } 76 \text {. }
$$

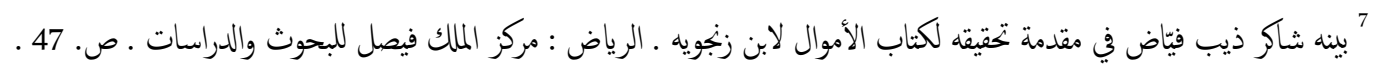

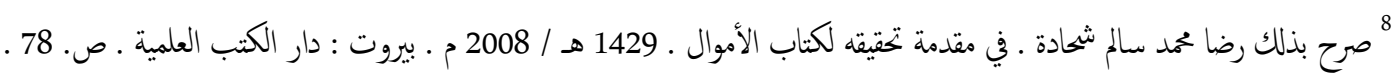

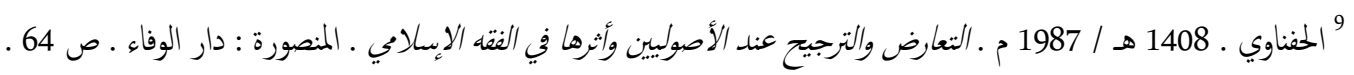

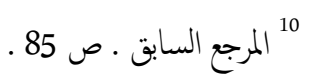


إذا كان سبب اختلاف الفقهاء التعارض بين النصين ، فإن لهم طرائق في ترجيح أحدهما

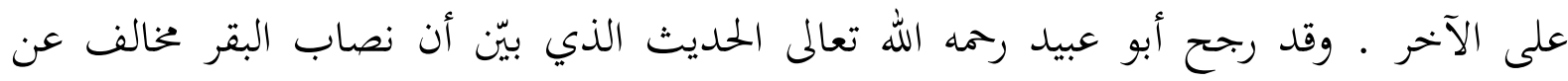

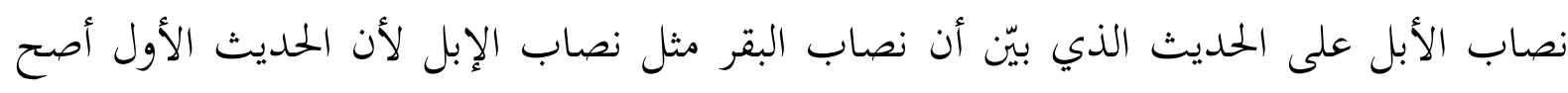

$$
\text { الثانية : التعارض بين المعقولين . }
$$

إذا كان سبب اختلافهم التعارض بين المعقولين ، حيث اعتمد بعضهم على قياس والبعض على آخر فإن لهم طرائق في ترجيح أحدها على الآخر ـ مثلما رجح أبو عبيد القول بعدم الزكاة

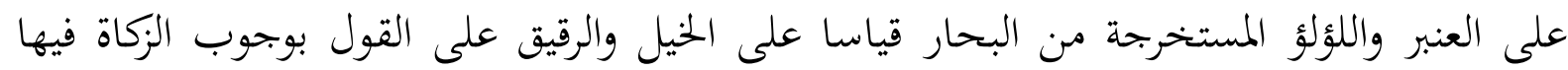
قياسا على المعادن في البر 12 . الثالثة : التعارض بين المعقول والمنقول وقد يكون سبب اختلافهم التعارض بين النص والقياس ، فلهم أيضا طرائق اتبعوها في

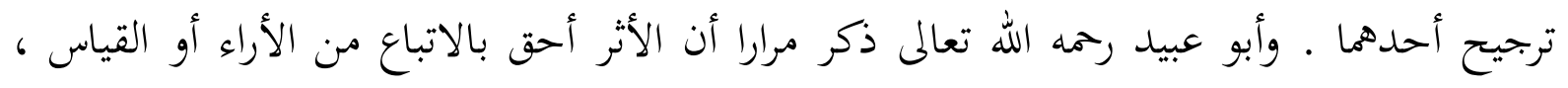
ويتضح ذلك في ترجيحه للنص الذي دل على عدم وجوب الزكاة في مال العبد والمكاتب على القول المبني على القياس في وجوب الزكاة في مالهما 13 قام الباحث بتفعيل نظرية الترجيح عند الجمهور وتطبيقها على ترجيحات أبي عبيد في

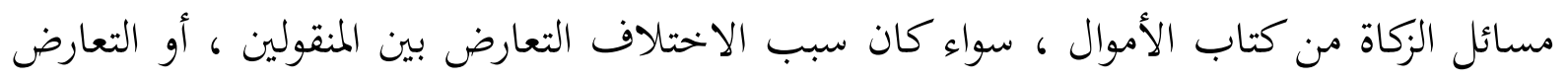
بين المعقولين، أو التعارض بين المعقول والمنقول.

\section{منهج البحث}

أما المنهج الذي أسير عليه في كتابة هذا البحث فهو يتلخص فيما يلي :

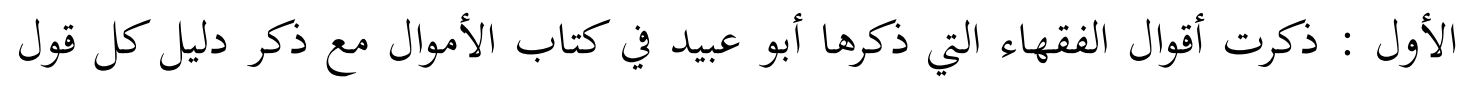
باختصار الثاني : أذكر ترجيحاته في مسائل الزكاة من كتابه مع بيان أسبابها وتعليلاهما .

$$
\begin{aligned}
& \text { 111 أبو عبيد ـ } 1428 \text { هـ / } 2007 \text { م . كتاب الأموال ـ المنصورة : دار الهدى النبوي ودار الفضيلة . المجلد } 2 \text { ص } 28 . \\
& \text { 12 المرجع السابق ـ المجلد } 1 \text { ص } 470 \text {. } 470
\end{aligned}
$$

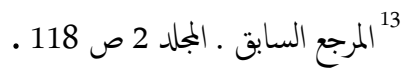


PROFETIKA, Jurnal Studi Islam, Vol. 19, No. 1, Juni 2018: 67-83

الثالث : أبين موقفي من ترجيحاته وأسبابها من حيث الموافقة والمخالفة مع بيان أسباب

3. جدول خلاصة ترجيحات أبي عبيد وأسبابها التفصيلية في الزكاة

\begin{tabular}{|c|c|c|c|c|}
\hline الباحث & أسباب & ترجيح & مسائل & رقم \\
\hline غير موافق & 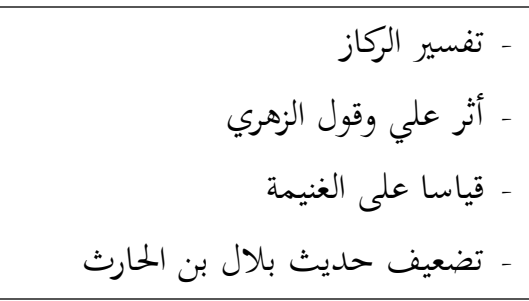 & مهس & زكاة المعادن & 1 \\
\hline غي - غير موافق & ـ ـ ـ أثر عمر وعلي : تخميسه الأشعري : لبيت المال & وكسية & زكاة الركاز & 2 \\
\hline غير موافق & ـ قياسا على الغنيمة & يعطى قليلا منه & عبد وجد الركاز & 3 \\
\hline موافق & 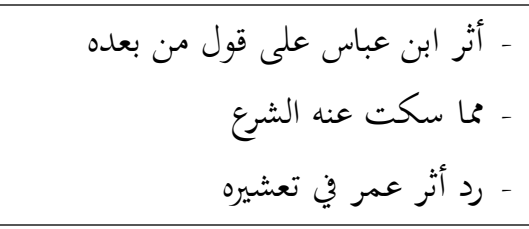 & لا زكاة & ما يخرجه البحر & 4 \\
\hline موافق & 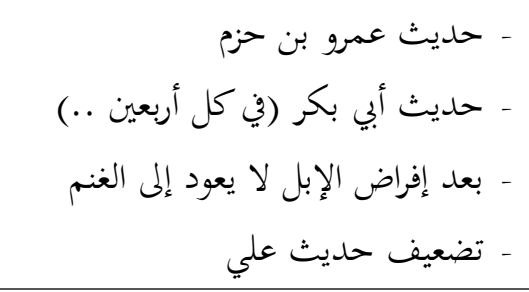 & بنتا لبون وحقة & زكاة الإبل بعد 120 & 5 \\
\hline غير موافق & ـ ـ ـ ـ أثر معاذ في أخذا الثياب في زكاة المال & - 1 - رد شاتين أو 10 - & ل الا يوجد السن & 6 \\
\hline غير موافق & ـ ـ عموم لفظ الإبل الذي ورد في الحديث & فيها السن الواجب & كل الإبل صغار & 7 \\
\hline غير موافق & - & لا زكاة فيها & 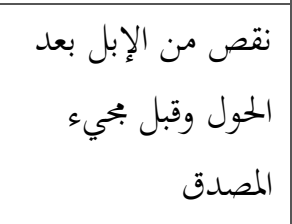 & 8 \\
\hline غير موافق & ـ ـ تأخير عمر زكاة سنتين عام الرمادة & فيها زكاة سنتين & حولان على الإبل & 9 \\
\hline
\end{tabular}


ترجيحات الإمام أبي عبيد القاسم (Muthoifin, Sudarno Humaidi)

\begin{tabular}{|c|c|c|c|c|}
\hline 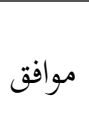 & تقديم حديث "في كل إبل سائمة" على الحديث & لا زكاة فيها & الإبل العوامل & 10 \\
\hline 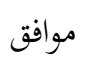 & تقديم حديث مسروق على حديثين ضعيفين & ليس مثل نصاب الإبل & نصاب البقر & 11 \\
\hline 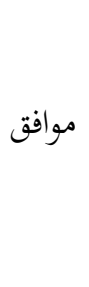 & 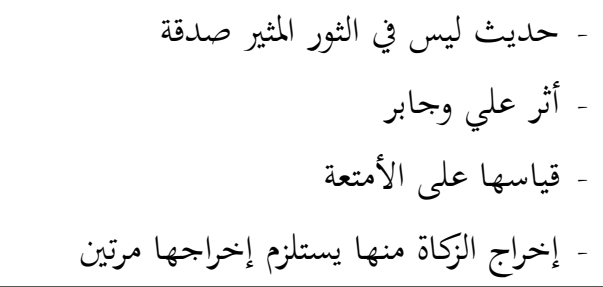 & لا زكاة فيها & البقر العوامل & 12 \\
\hline 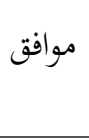 & ـ ـ ـ ـ أثر الشعبي وعمر بن عبد العزيز & لا زكاة فيها & زكاة الأوقاص & 13 \\
\hline 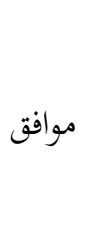 & - & ضم أحدهما للأخر & البقر خالطت الإبل & 14 \\
\hline 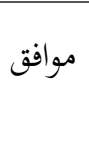 & ـ ـ ـ أسباب في مسألة " "كل الإبل صغار" لحديث سفيان بن عبد الله الثففي & فيها السن الواجب & كل الغنم صغار & 15 \\
\hline 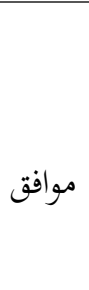 & 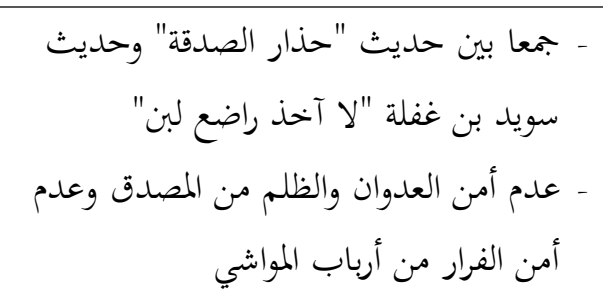 & ول النهي موجه للمصدق & البمتمع المتفرق وتفريق & 16 \\
\hline 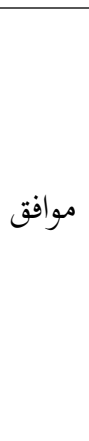 & ـ ـ ـ ـ علىيث السائب بن يزيد "الخليطان ما اجتمعا & واجتماع الماء والفحل & معنى الخليطين & 17 \\
\hline 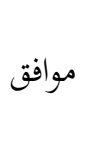 & ـ قياسه على التغليط في اعتداد البهم والسخال & وصول بحموع ما عند & شرط المخالطة & 18 \\
\hline 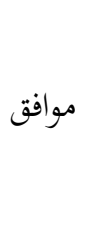 & 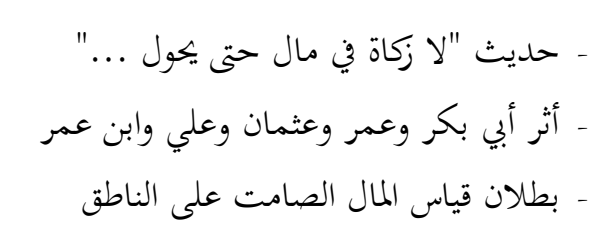 & لا زكاة حتى يحول عليه & زاد النصاب وعلد الحول الحول النصاب & 19 \\
\hline 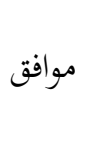 & ـ أثر عمر بن عبد العزيز والليث وقول إبراهيم & صارت الزئناف الحول من يوم & 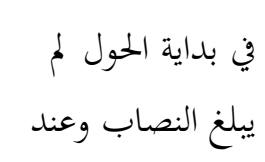 & 20 \\
\hline
\end{tabular}


PROFETIKA, Jurnal Studi Islam, Vol. 19, No. 1, Juni 2018: 67-83

\begin{tabular}{|c|c|c|c|c|}
\hline & ـ لا فرق بين النتاج والأرباح وبين غيرهما لأفما & & الحول بلغ النصاب & \\
\hline موافق & 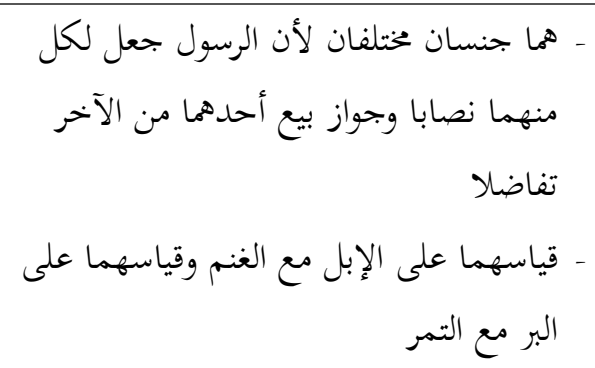 & لأحدهاة فيهما ولا يضم & رجل & 21 \\
\hline موافق & 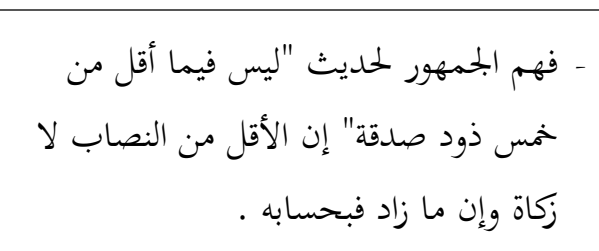 & - & 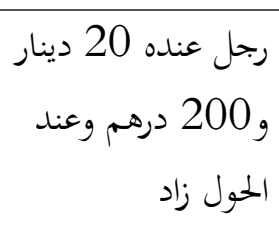 & 22 \\
\hline موافق & ـ ـ ـ مذهب الصحاة في قيمة العروض أسهل والتعين وجمهور الفقهاء على المهيف للتاجر & تقويم العروض ثماب الدين الذي المين & زكاة عروض التجارة & 23 \\
\hline موافق & ـ ـ المال في المرجو بمنزلة ما بيده في غير المرجو ما زال ملكا له كالوديعة & 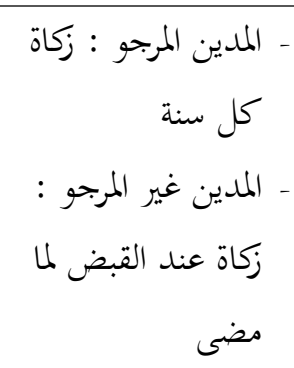 & من له مال على غيره & 24 \\
\hline موافق & - & لا يجزئ & جعل الدين زكاة & 25 \\
\hline غير موافق & 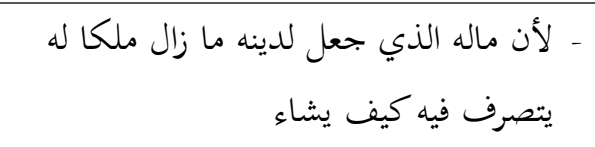 & عليه زكاة & من عليه دين & 26 \\
\hline موافق & 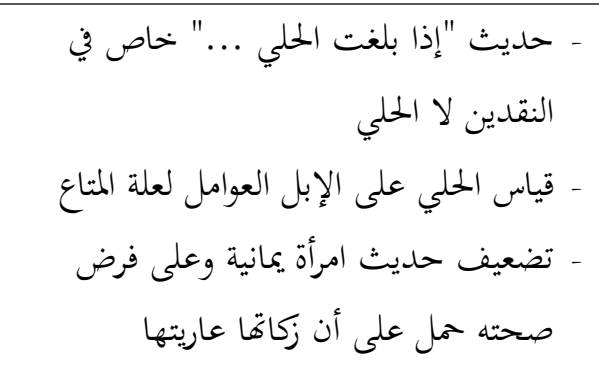 & لا زكاة فيها & زكاة الحلي & 27 \\
\hline موافق & 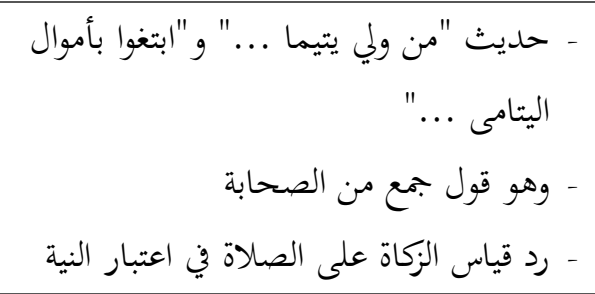 & فيه الزكاة & زكاة مال اليتيم & 28 \\
\hline
\end{tabular}


ترجيحات الإمام أبي عبيد القاسم (Muthoifin, Sudarno Humaidi)

\begin{tabular}{|c|c|c|c|c|}
\hline & ـ رد أثر ابن مسعود & & & \\
\hline موافق مو & 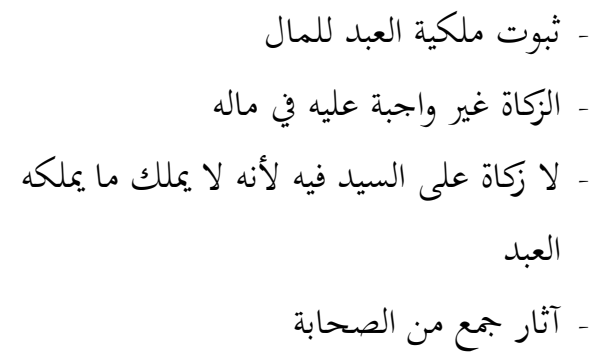 & لا زكاة فيه على السيد & زالماة مال العبد على & 29 \\
\hline موافق & ـ ـ ـ صموم حديث "عفونا لكم عن صدقة ..." & لا زكاة فيهما & زكاة الخيل والرقيق & 30 \\
\hline غير موافق & ـ - مديث معاذ وأثر ابن عمر & الزأربعة مقصورة في & أصناف النباتات & 31 \\
\hline موافق & ـ قياسا على عدم ضم الذهب إلى الفضة & الضم الخنسه وعدم لغير جنسه & ضم نوع إلى نوع & 32 \\
\hline موافق & 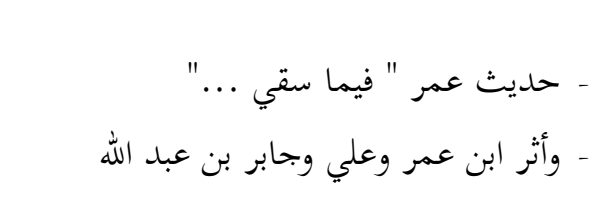 & العشر فيما لا مؤنة في & مقدار الزكاة & 33 \\
\hline موافق & - ـ - حديث أبي سعيد & خمسة أوسق & نصابه & 34 \\
\hline موافق م & - ـ - ملايث أبي حميد الساعدي & تخرص عند بدو & خرص الثمار & 35 \\
\hline موافق & ـ ـ حديث أبي سهل بن ابي حثمة الخذري & - مترك - مترك الثلث - مترايا & استثناء في الخرص & 36 \\
\hline موافق & ـ ـ لغير المعين ، صرفها إلى مستحقي الزكاة & 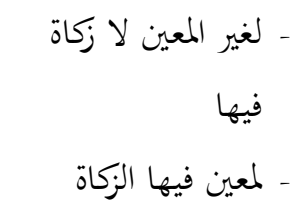 & المواشي المسبلة & 37 \\
\hline موافق & ـ ـ ـمل الآثار فحة ذلك السنة في زكاة العسل على الحث على الصدقة & لا زكاة فيها لكن يُحث & زكاة العسل & 38 \\
\hline موافق & 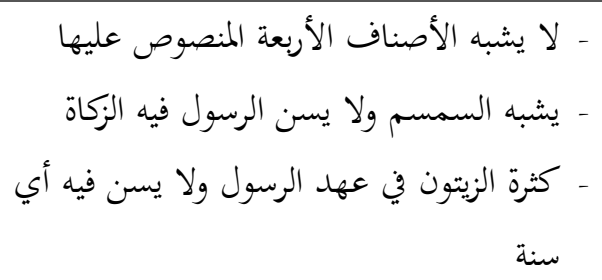 & لا زكاة فيه & زكاة الزيتون & 39 \\
\hline
\end{tabular}


PROFETIKA, Jurnal Studi Islam, Vol. 19, No. 1, Juni 2018: 67-83

\begin{tabular}{|c|c|c|c|c|}
\hline & - ضعف أثر عمر وابن عباس & & & \\
\hline موافق & 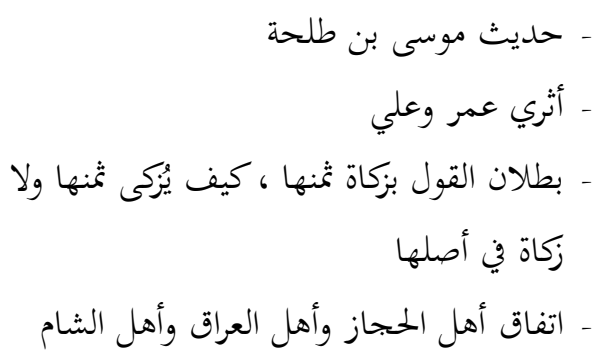 & لا زكاة فيها & زكاة الخضر & 40 \\
\hline موافق & ـ ـ الجمع بين القولين بثبوت البينة أو عدم ثبوقا، & $\begin{array}{r}\text { بينة والذي ليست الدين الذي له له } \\
\text { بينة }\end{array}$ & هل الدين يمنع الزكاة & 41 \\
\hline موافق & 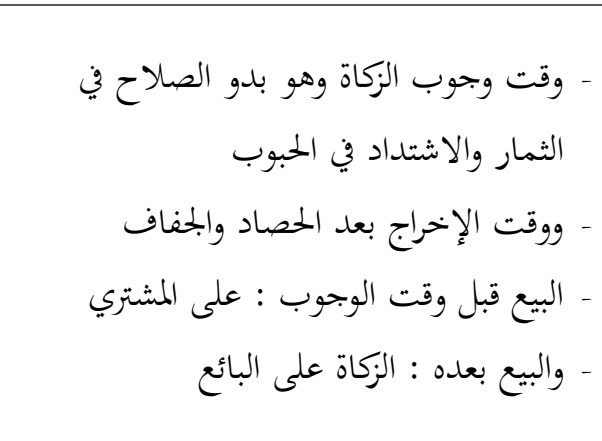 & 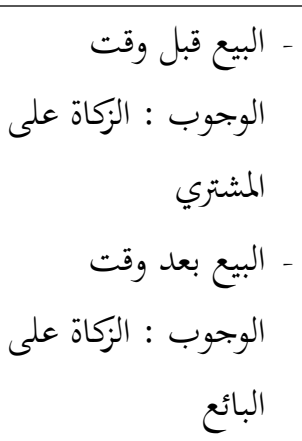 & بيع الثمار والزروع & 42 \\
\hline موافق م & ـ ذكر قوله فقط دون قول غيره & أربعة أنواع & أنواع الأرض العشرية & 43 \\
\hline موافق & 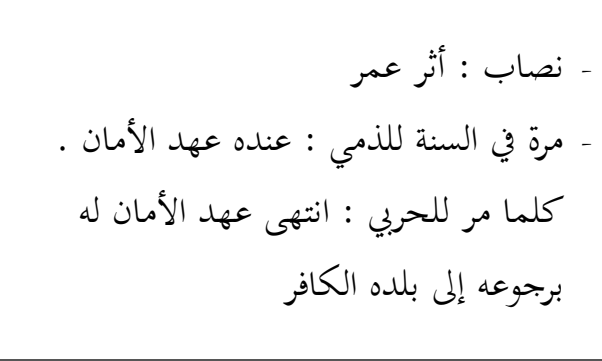 & 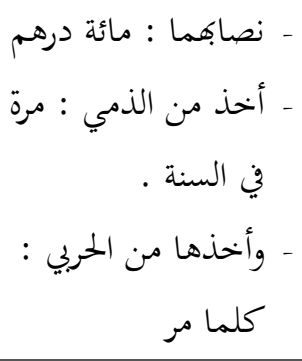 & تبحار الحربي والذمي & 44 \\
\hline غير موافق & ـ ـ ـ ـ ـديث أثريث أوقية عن عطاء وهو أصح & تمليك أوقية فاضلة عن & حد الغنى & 45 \\
\hline موافق مو & 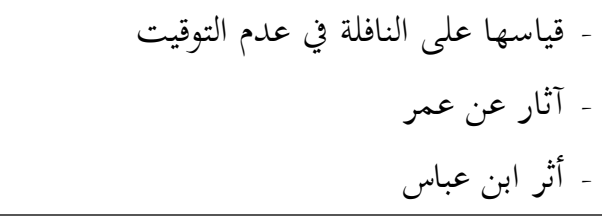 & حسب اجتهاد الإمام & قالزبر ما يعطى من & 46 \\
\hline موافق في & - أر الإمام بمنزلة الولي في الأموال الظاهرة & $\begin{array}{l}\text { - الأموال الظاهرة : الأموال الباطنة : للأمراء } \\
\text { - مفوضة إل أرباهما }\end{array}$ & دفع الزكاة إلى الأمراء & 47 \\
\hline موافق & - ـ دون ذكر السبب & & أخذها العاشر & 48 \\
\hline
\end{tabular}


ترجيحات الإمام أبي عبيد القاسم (Muthoifin, Sudarno Humaidi)

\begin{tabular}{|c|c|c|c|c|}
\hline & & محسوبة من الزكاة & & \\
\hline 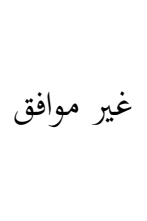 & - صحة الإمامة في قريش فقط & 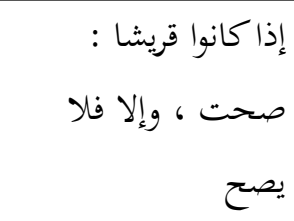 & وفنها إلى البغاة & 49 \\
\hline 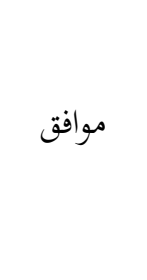 & ـ ـ ـ ـقديث قبيصة بن المخارق فيه ذكر الفقراء & لا يجب & تفريقها إلى الثمانية & 50 \\
\hline 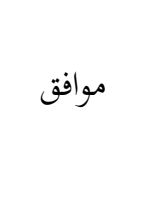 & 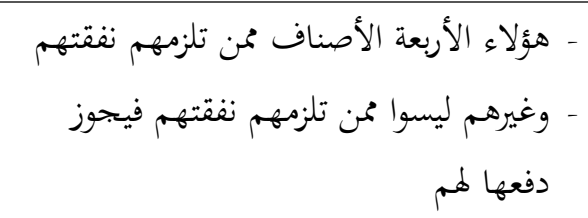 & تصح إلا للوالدين & الأقارب الزكاة إلى & 51 \\
\hline 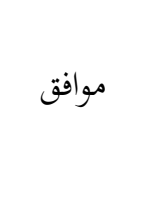 & 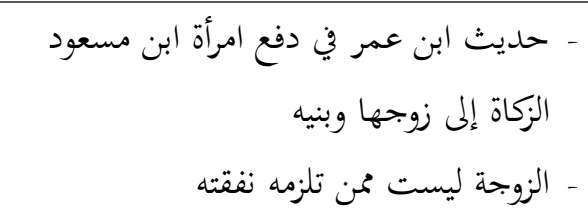 & يجوز & لز لزع المرأة الزكاة & 52 \\
\hline 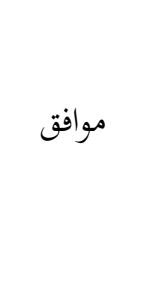 & 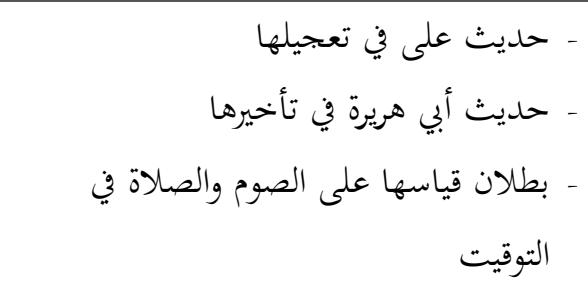 & يجوز & وتعجيل الزكاة & 53 \\
\hline 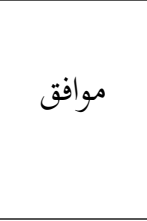 & 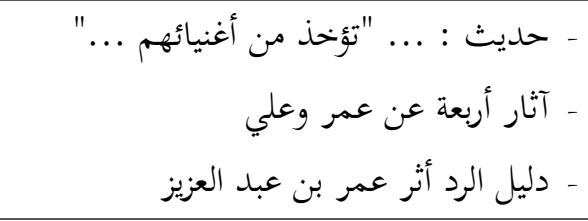 & لا لا يجوز وعلى الإمام & نقل آزل آزكاة إلى بلد & 54 \\
\hline 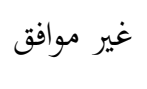 & - لم يتحقق معنى الإيتاء إلى الفقراء & تجب إعادتا & ضاعت الزكاة & 55 \\
\hline 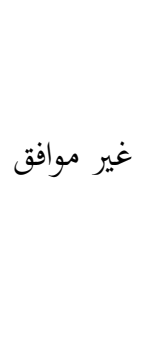 & 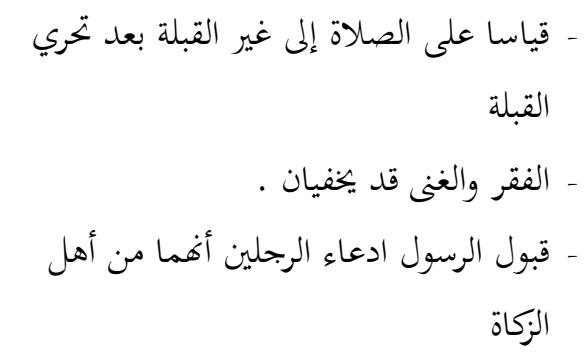 & صحت الزكاة & لا دفها إلى غني وهو & 56 \\
\hline غير موافق & ـ ذـكر الأقول في بيان بعض أوصاف الفقير & لا يعطي حدا معينا & حد الفقير والمسكين & 57 \\
\hline 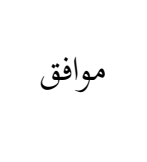 & - & غير إلى الإمام ويرجع أمره & سهم العامل & 58 \\
\hline
\end{tabular}


PROFETIKA, Jurnal Studi Islam, Vol. 19, No. 1, Juni 2018: 67-83

\begin{tabular}{|c|c|c|c|c|}
\hline موافق مق & 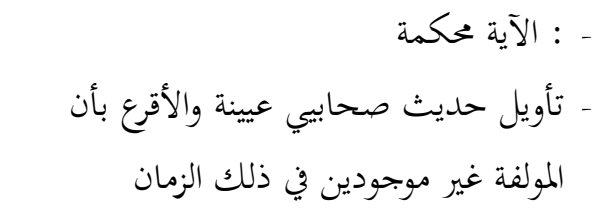 & 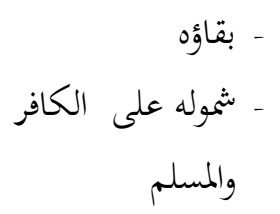 & سهم المؤلفة القلوب & 59 \\
\hline موافق مو & - ـ ـ أثر ابن عباس "وجبث أجرك وردها إليك الميراث & يجيجوز & عتق الرقبة من الزكاة & 60 \\
\hline غبر موافق & - لا - دين الميت ينتقل إلى الورثة عليهم قضاؤ لأفم ليسوا من & لا لا يصح & الزضاة & 61 \\
\hline غير موافق & ـ ـ ـ قديث غاز "لا تحل الصدقة لغني إلا لخمسة ... & الغزاة فقط & سبيل الله & 62 \\
\hline غير موافق & ـ أثر عمر & المنقطع في السفر & ابن السبيل & 63 \\
\hline موافق & ـ ـ حديث "... تؤخذ من أغنيائهم ..." & لا يجوز & دفع الزكاة إلى الذمي & 64 \\
\hline موافق & 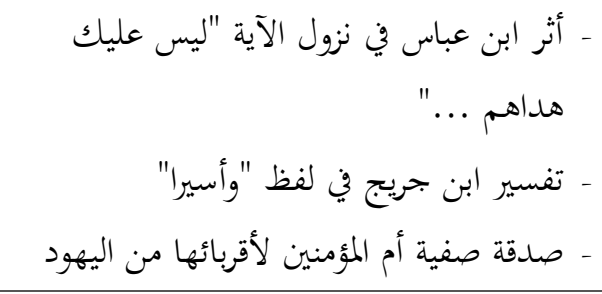 & بيجوز & دفع الصدقة النافلة & 65 \\
\hline غير موافق & - قول عمرو بن ميمون وعمرو بن شرحبيل ومرة & 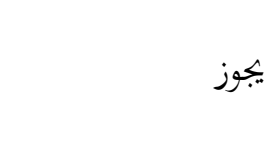 & لمفع زكاة الفطر & 66 \\
\hline
\end{tabular}

\section{4. - أسباب ترجيحاته الإجمالية}

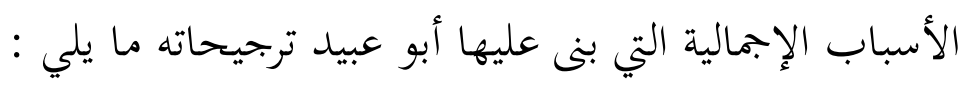

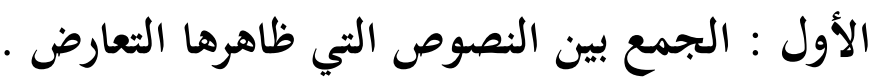

وطريقة جمعه إما أن يأخذ نصين معا ولا يرجح أحدهما على الآخر . كجمعه بين نصين في

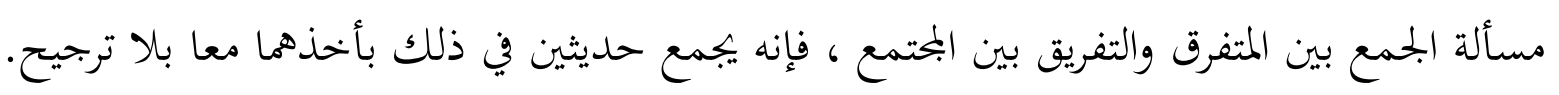

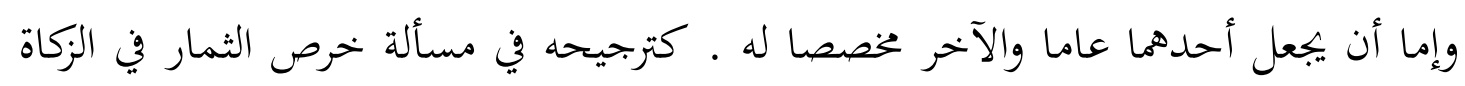
، فإنه يجمع بين ثلاثة أحاديث بجعل أحدها عاما وهو حديث خرص الثمار ، و وجعل الحديثين

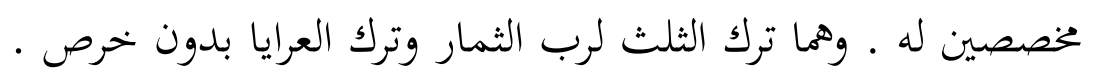


وكترجيحه في مسألة نصاب زكاة الزروع ، فإنه جعل حديث خمسة أوسق مخصصا لحديث

$$
\text { فيما سقي بالسماء العشر وفيما سقي بالنضخ نصفه . }
$$

وطريقة ترجيحه تقديم النص الصحيح على النص الضعيف ـ ـ كترجيحه في مسألة نصاب النصوه البقر ، حيث رجح أبو عبيد الحديث الدالة على أن البقر له نصاب مخالف لنصاب لنصاب الإبل لأنه

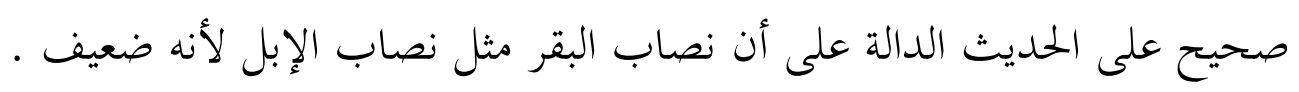

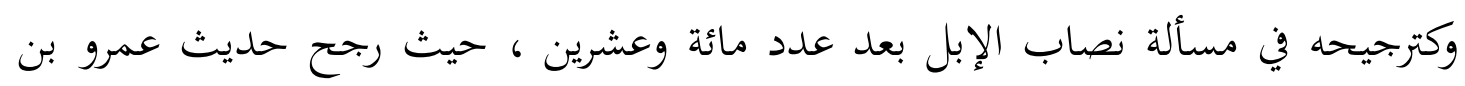

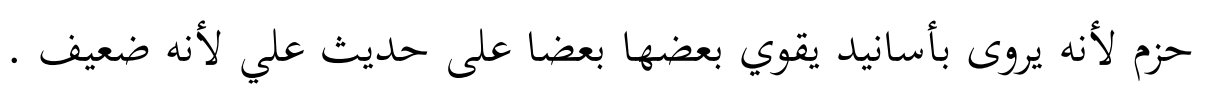

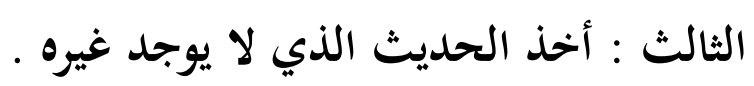

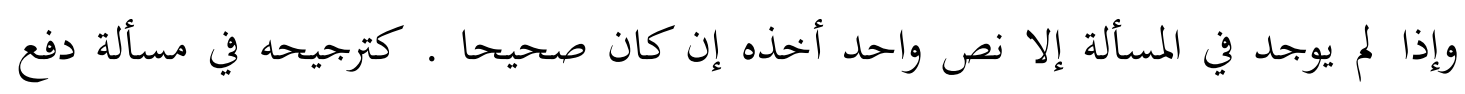

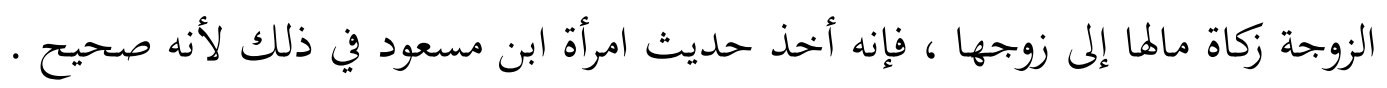

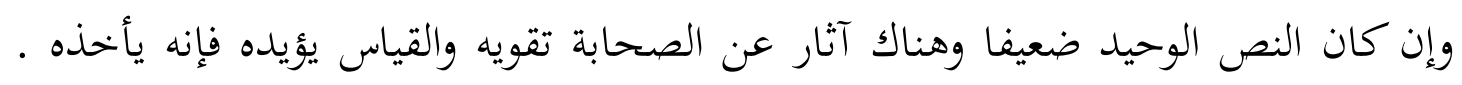

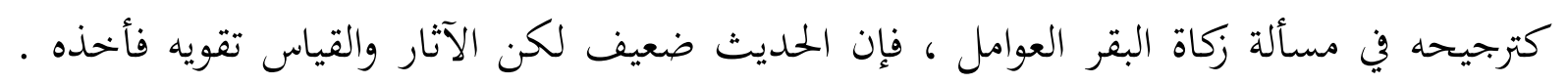
وكترجيحه في مسألة زكاة العسل وفي معنى الخنليطين في زكاة الغنم وفي زكاة الأوقاص وفي زكاة لهاة

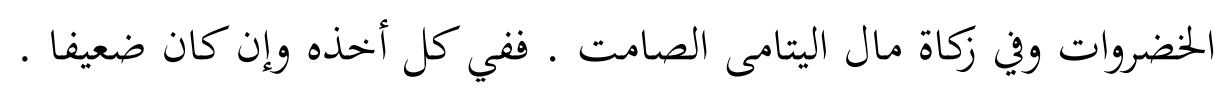
الرابع : تمسكه بظاهر النص . تمسك أبو عبيد بظاهر الحمديث دون البحث عن علة الحكم فيه ـ كترجيحه في مسألة أنواع

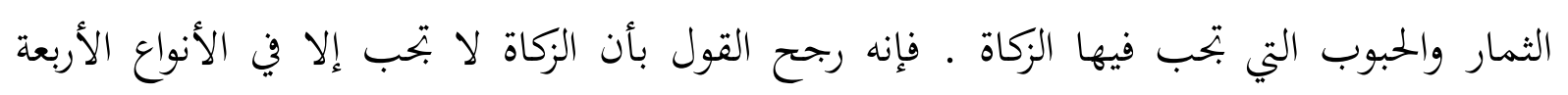

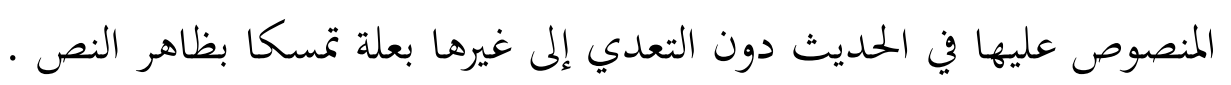
الخامس : تقديم النص على الأثر والقياس . يقدم أبو عبيد النص على الآثار والقياس مادام النص صحيحا ـ ـ كترجيحه في مسألة تعجيل

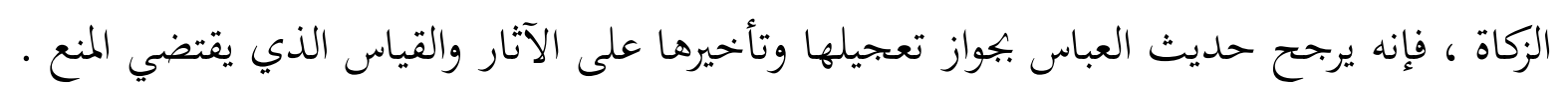

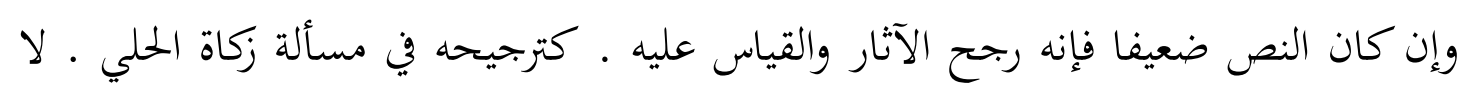

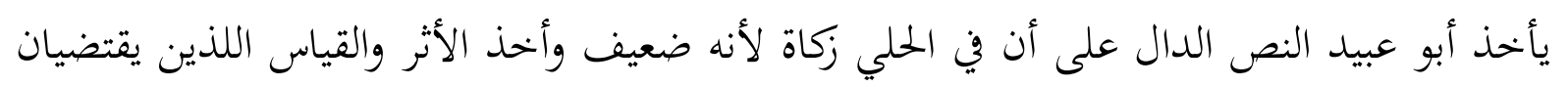

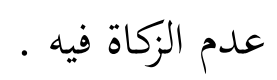

السادس : تقديم آثار الصحابة على أقوال من دونهم . 
عند التعارض بين الصحابة وأقوال من دوفم ، فإنه يرجح أثر الصحابة لأغم شاهدوا التنزيل

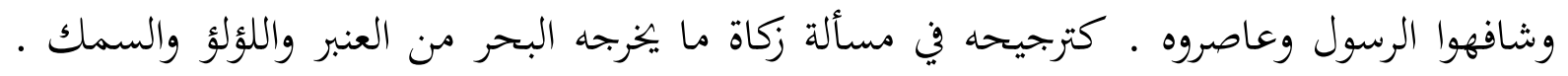

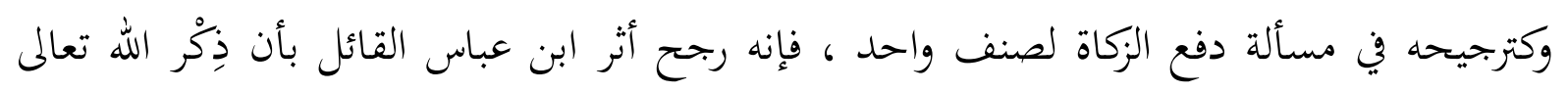

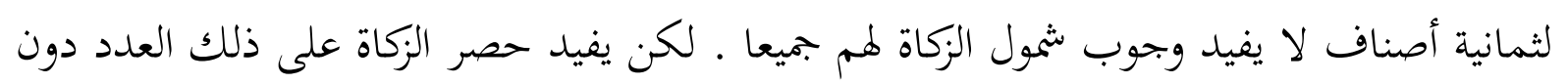
غيرهم . غ

وحين تعارضت آثار الصحابة ، فإنه يرجح الأثر الذي يقويه نص على الأثر الذي لا يقويه .

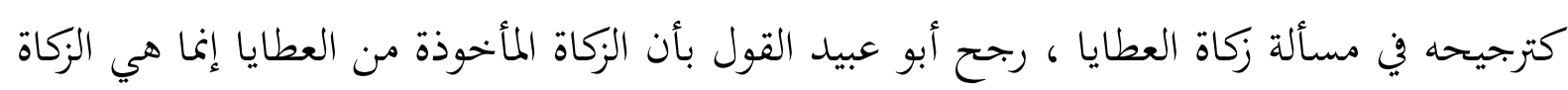

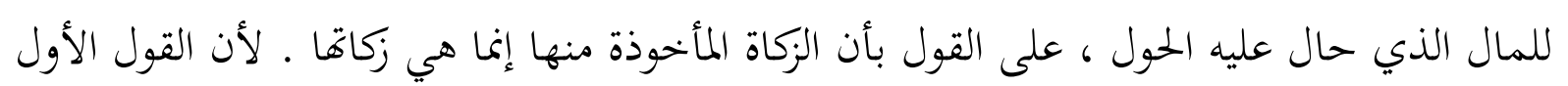
يقويه حديث لا زكاة لمال حتى يمول عليه الحول . السابع : تقديم القياس الذي يشهده النص أو المبادئ العامة في الدين . لمادئ

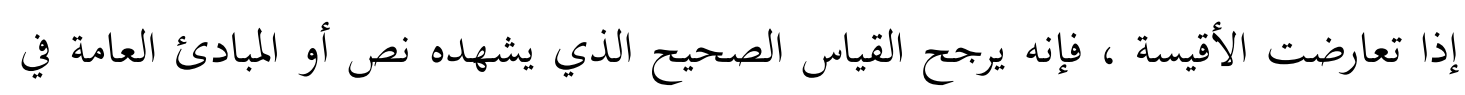
الدين على القياس الذي لا يشهده ذلك ـ كترجيحه في مسألة دفع الزكاة لمن يطن أنه فقير وتبين

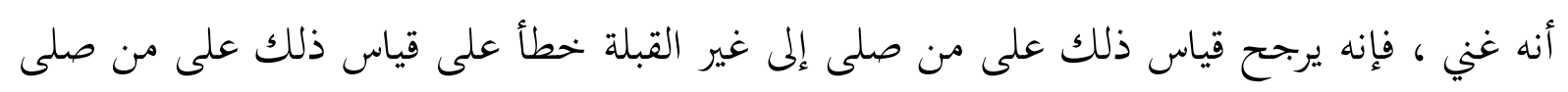

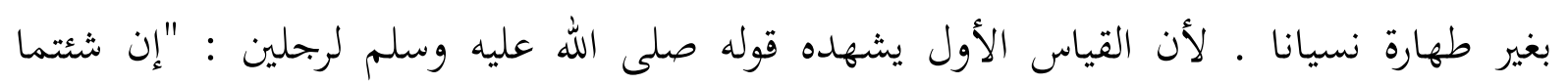

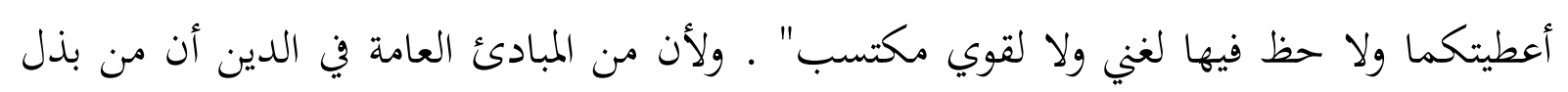

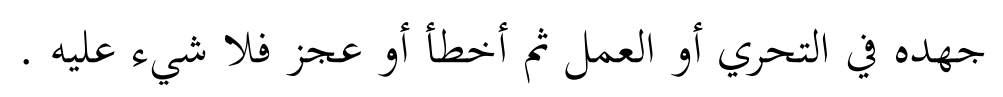

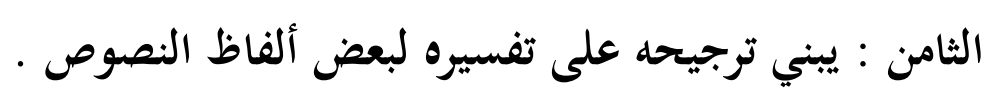

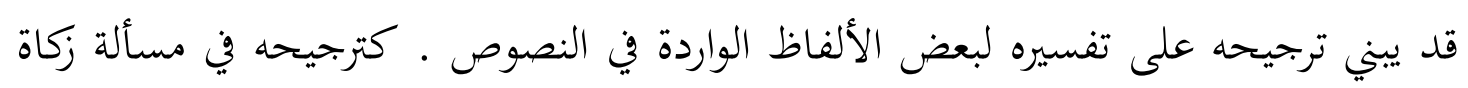

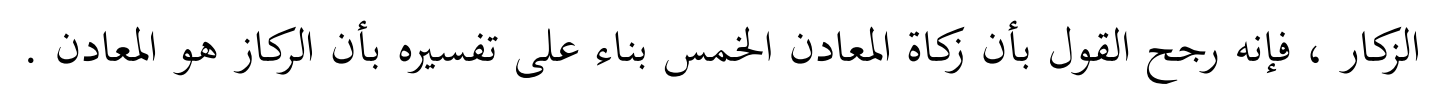

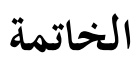

أسأل الله أن ينفع الله بهذا البحث هذه الأمة ويجعله في ميزان حسناتي يوم لا ينفع مال ولا ينون إلا من آتى الله بقلب سليم . 
ابن زبهويه . بدون تاريخ الطباعة . كتاب الأموال . الرياض : مركز الملك فيصل للبحوث والدراسات الإسلامية .

ابن كثير 1421 هـ/ 2000 م . تنسير القرآن العظيم ـ جيزة : مكتبة قرطبة ومكتبة أولاد الشيخ للتراث .

أبو عبيد ـ 1428 هـ / 2007 م . كتاب الأموال ـ المنصورة : دار الهدى النبوي ودار الفضيلة . الخطيب البغدادي ـ 1422 هـ / 2001 م . تاريخ ملدينة السلام وأخبار محاثيها وذكر قطانا العلماء من غير أهلها ووارديها ـ بيروت : دار الغرب الإسلامي .

الحفناوي ـ 1408 هـ / 1987 م ـ التعارض والترجيح عند الأصوليين وأثرها في الفقه الإسلامي . المنصورة : دار الوفاء . الذهبي ـ 1405 هـ / 1985 م ـ سير أعلام النبلاء ـ بيروت : مؤسسة الرسالة . 